\title{
Stability of Melphalan in $0.9 \%$ Sodium Chloride Solutions Prepared in Polyvinyl Chloride Bags for Intravenous Injection
}

\author{
Romain-Pacôme Desmaris ${ }^{1} \cdot$ Lionel Mercier $^{1} \cdot$ Angelo Paci $^{1}$
}

Published online: 16 July 2015

(c) The Author(s) 2015. This article is published with open access at Springerlink.com

\begin{abstract}
Melphalan is an alkylating agent frequently used in an intravenous formulation to treat hematologic malignancies and solid tumors in both adults and children. According to the manufacturer, melphalan is stable in sterile $0.9 \%$ sodium chloride for $90 \mathrm{~min}$ at room temperature (RT). Several authors have studied the stability of different concentrations of melphalan; however, most were not adapted to the current manufacturing process applied in pharmaceutical centralized units. This study was conducted to determine the stability of melphalan in $0.9 \%$ sodium chloride solutions at concentrations used for intravenous injection in practice. Melphalan is commonly prepared in diluted solutions ranging from 2 to $4 \mathrm{mg} / \mathrm{ml}$ for the treatment of adult patients and at lower concentrations (down to $0.5 \mathrm{mg} / \mathrm{ml}$ ) for pediatric use. Accordingly, these were the three concentrations chosen for this study. Melphalan concentrations were measured with high-performance thinlayer chromatography (HPTLC). At RT, admixtures prepared at $4 \mathrm{mg} / \mathrm{ml}$ were stable for up to $8 \mathrm{~h}$ without protection from light; however, at lower concentrations, such as 0.5 and $2 \mathrm{mg} / \mathrm{ml}$, stability did not exceed $2 \mathrm{~h}$. When refrigerated, melphalan was stable for $24 \mathrm{~h}$ at $2 \mathrm{mg} / \mathrm{ml}$; however, at 0.5 and $4 \mathrm{mg} / \mathrm{ml}$, the drug was not stable.
\end{abstract}

Romain-Pacôme Desmaris

romain.desmaris@gustaveroussy.fr

Lionel Mercier

lionel.mercier@gustaveroussy.fr

Angelo Paci

angelo.paci@gustaveroussy.fr

1 Department of Clinical Pharmacy, Gustave Roussy Hospital, 114 Rue Edouard Vaillant, 94805 Villejuif Cedex, France
Melphalan solutions present with limited stability at $0.5,2$, and $4 \mathrm{mg} / \mathrm{ml}$ and are not adapted for delayed administration in pharmaceutical centralized units. However, at $4 \mathrm{mg} /$ $\mathrm{ml}$ and at RT, a stability of $8 \mathrm{~h}$ is very interesting in practice and allows sufficient time for preparation, pharmaceutical control, transport, and administration.

\section{Introduction}

Melphalan is an alkylating agent available as either an oral or an intravenous formulation and used to treat malignancy in both adult and pediatric patients. Melphalan is a major drug against hematological malignancies (multiple myeloma, Hodgkin or non-Hodgkin lymphoma, lymphoid leukemia, or myeloid acute leukemia), solid tumors such as ovarian or breast cancers, and children's neuroblastoma with posologies comprising between 100 and $200 \mathrm{mg} / \mathrm{m}^{2}$ according to the summary of product characteristics (SmPC) [1]. Melphalan is mainly used as intensive treatment supported by autologous stem-cell transplantation and administered alone in multiple myeloma at $140-200 \mathrm{mg} / \mathrm{m}^{2}$, and at $100-140 \mathrm{mg} / \mathrm{m}^{2}$ in combination with other cytotoxic drugs (such as busulfan) in pediatric solid tumors (neuroblastoma, Ewing's sarcoma, peripheral neuroectodermal tumor, rhabdomyosarcoma) [2-4]. In our institution, an off-label use of melphalan includes isolated limb or pelvic perfusion at $1.5 \mathrm{mg} / \mathrm{kg}$ [5]. According to the manufacturer, melphalan is stable in $0.9 \%$ sodium chloride for no longer than $90 \mathrm{~min}$ at room temperature (RT) [1]. Melphalan is commonly used in diluted solutions ranging from 2 to $4 \mathrm{mg} / \mathrm{ml}$ for adults; for pediatric use, lower concentrations (down to $0.5 \mathrm{mg} / \mathrm{ml}$ ) are frequently used in pediatric patients. 


\section{Aim of the Study}

Several works have studied the stability of melphalan in polyvinyl chloride (PVC) bags. Beitz and colleagues $[6,7]$ reported a stability of $24 \mathrm{~h}$ when $0.9 \%$ sodium chloride solutions at $0.06 \mathrm{mg} / \mathrm{ml}$ were stored at $4{ }^{\circ} \mathrm{C}$, while this duration was reduced to $90 \mathrm{~min}$ when those solutions were stored at $23{ }^{\circ} \mathrm{C}$ without protection from light exposure. Pinguet et al. [8] reported a stability of $6 \mathrm{~h}$ when $0.9 \%$ sodium chloride solutions of melphalan prepared at $0.2 \mathrm{mg} / \mathrm{ml}$ were stored at $4{ }^{\circ} \mathrm{C}$ and protected from light. Chang et al. [9] reported that melphalan hydrolysis decreased when sodium concentration increased [9]. These data were confirmed by Pinguet et al. [8], who showed that melphalan was stabile for longer when it was diluted in a $3 \%$ sodium chloride solution. In our institution, to avoid error with the isotonic form, the use of hypertonic sodium chloride solution is not recommended. More recently, B. BRAUN AG, Melsungen, Germany, medical devices manufacturer, studied the stability of melphalan in $0.9 \%$ sodium chloride solutions in Ecoflac ${ }^{\circledR}$ bags (flexible bags made from polyethylene). They demonstrated that $0.06 \mathrm{mg} / \mathrm{ml}$ melphalan solution was stable for $24 \mathrm{~h}$ when stored at $4{ }^{\circ} \mathrm{C}$ and for $2 \mathrm{~h}$ at $22{ }^{\circ} \mathrm{C}$ under the same conditions [10]. These few published data provide information about the manufacturing process for very low concentrations of melphalan administered to patients. Hospital pharmacists need more detailed information about the stability of this diluted drug at higher concentrations, according to current clinical practice. Further data regarding the stability of melphalan in solutions prepared at $2-4 \mathrm{mg} / \mathrm{ml}$ are currently lacking. In order to acquire novel experience on the stability of melphalan at these higher concentrations commonly used in daily clinical practice, we conducted a physico-chemical stability study of melphalan solutions prepared at $0.5,2$, and $4 \mathrm{mg} / \mathrm{ml}$ in $0.9 \%$ sodium chloride stored at both refrigerated temperatures $\left(5 \pm 3{ }^{\circ} \mathrm{C}\right)$ and RT $\left(25 \pm 2{ }^{\circ} \mathrm{C}\right)$. By conducting this study, we intended to optimize the manufacturing production schedule in a centralized unit to improve patient care management with the possibility of preparing these infusion bags with a prolonged duration of storage.

\section{Materials and Methods}

\subsection{Materials}

Alkeran ${ }^{\circledR}$ (melphalan $5 \mathrm{mg} / \mathrm{ml}$ ) for intravenous use from GlaxoSmithKline (batch no. 7004) was used. Melphalan (Fig. 1) was reconstituted with its specific solvent $(10 \mathrm{ml}$

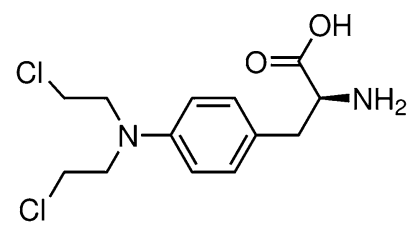

Fig. 1 Chemical structure of melphalan 2-amino-3-[4-(2-(dichloroéthyl)amino)phényl] propanoïc acid

of sterile water with a mixture of sodium citrate, propylene glycol, and alcohol in injectable water) to obtain a final concentration of $5 \mathrm{mg} / \mathrm{ml}$ in each glass vial as recommended in the SmPC by the manufacturer [1]. Emptied PVC bags by Maco Pharma with a $100 \mathrm{ml}$ volume of capacity (batch $07 \mathrm{~B} 15 \mathrm{H}$ ) were used. For the degradation study, $0.1 \mathrm{M}$ hydrochloric acid $(0.1 \mathrm{M} \mathrm{HCl})$ and $0.1 \mathrm{M}$ sodium hydroxide $(0.1 \mathrm{M} \mathrm{NaOH})$ were provided by Prolabo-VWR International SA, and $10 \%$ hydrogen peroxide $\left(10 \% \mathrm{H}_{2} \mathrm{O}_{2}\right.$ ) by Cooper.

\subsection{Preparation, Storage, and Sampling}

Melphalan admixtures (diluted solutions) were prepared by filling emptied PVC bags with melphalan reconstituted solution at $5 \mathrm{mg} / \mathrm{ml}$ and $0.9 \%$ sodium chloride solution to achieve the three drug concentration levels (4, 2, and $0.5 \mathrm{mg} / \mathrm{ml})$. PVC bags were filled to final volume of $50 \mathrm{ml}$. All admixtures (18 total, six for each concentration and three for each concentration and each temperature) were prepared in a vertical laminar airflow hood to ensure aseptic conditions and to protect operators from toxic effects. Concentration ranges of melphalan were defined according to clinical practice in our hospital $(0.5 \mathrm{mg} / \mathrm{ml}$ for pediatric use, 2 and $4 \mathrm{mg} / \mathrm{ml}$ for adults).

The effect of temperature during storage was investigated. Bags were stored at refrigerated temperature $\left(5 \pm 3{ }^{\circ} \mathrm{C}\right)$ or at RT $\left(25 \pm 2{ }^{\circ} \mathrm{C}\right)$. Bags stored at RT were not protected from light, while bags at $5{ }^{\circ} \mathrm{C}$ were protected from light. However, almost no data on the influence of light on melphalan stability are available.

At the end of the preparation, the admixture samples were removed at defined intervals ranging from 0 to $24 \mathrm{~h}$. The sampling was as follows: at the end of the preparation (H0), after $1 \mathrm{~h}(\mathrm{H} 1), 2 \mathrm{~h}(\mathrm{H} 2), 4 \mathrm{~h}(\mathrm{H} 4), 6 \mathrm{~h}(\mathrm{H} 6), 12 \mathrm{~h}$ (H12), and $24 \mathrm{~h}$ (H24). We expected the stability of melphalan solutions at RT to be reduced compared with those stored at $5{ }^{\circ} \mathrm{C}$; therefore, additional samples after $8 \mathrm{~h}(\mathrm{H} 8)$ and $16 \mathrm{~h}$ (H16) were obtained for bags stored at RT. Samples were not treated immediately but stored in adequate conditions protected from light and at $-20{ }^{\circ} \mathrm{C}$. 


\subsection{Chromatographic Analysis and Analytical Validation}

Melphalan concentrations were measured via high-performance thin-layer chromatography (HPTLC CAMAG ${ }^{\circledR}$ ) combined to an ultraviolet (UV) detection with fluorescence extinction quantitation. This analytical method has been previously developed and published and has been routinely used in our quality control (QC) laboratory for several years for 39 compounds, including melphalan. The assessment of the temperature storage conditions has been validated during the analytical validation carried out for each developed analytical method. Samples of melphalan can be frozen without degradation [11-13]. Validation was conducted by evaluating common parameters defined by the International Conference of Harmonization (ICH) [14] such as specificity, linearity, accuracy, precision (repeatability and intermediate precision), and limits of detection (LOD) and quantification (LOQ). The parameters were determined by the statistical analysis of six calibration plots. The stationary phases (Lichrospher ${ }^{\circledR}$ Si60F254 nm), manufactured by Merck, were made of uniform $0.2 \mathrm{~nm}$ thin silica layers that were placed on a glass surface of $20 \times 10 \mathrm{~cm}$. Sample application was standardized: automated TLC sampler III ${ }^{\circledR}$ devices take into account defined parameters such as the volume, size of the sprayed band, and accurate positioning on the chromatography plate. These parameters were computerized by ATS III ${ }^{\circledR}$ software. After migration, the plate was analysed on a TLC scanner $3^{\circledR}$ densitometer driven by CATS $4^{\circledR}$ software as previously reported [11]. The HPTLC analysis station by $\mathrm{CAMAG}^{\circledR}$ is composed of a HPTLC Vario-chamber for mobile phase optimization, automated sample applicators (TLC Sampler III), which manage the calibrated applications of sampled solutions (volume required is $500 \mathrm{~nL}$ ), solid Teflon ${ }^{\circledR}$ (PFTE) migration chambers, and a TLC Scanner $3^{\circledR}$ densitometer driven by a winCATS ${ }^{\circledR}$ software. Accuracy results, providing information about the recovery of the analyte from the sample, are summarized in Table 1. Means and relative standard deviation (RSD) values were calculated from the six determinations of each QC with three different known concentrations of melphalan, which were classified as low, medium, and high (QCL, QCM, and

Table 1 Results of the accuracy study

\begin{tabular}{llll}
\hline & QCL & QCM & QCH \\
\hline Mean $^{\mathrm{a}}$ & $150.5(150)$ & $250.0(250)$ & $458.2(450)$ \\
RSD & 5.89 & 9.83 & 17.99 \\
\hline
\end{tabular}

$Q C H$ high quality control, $Q C L$ low quality control, $Q C M$ medium quality control, $R S D$ relative standard deviation

a Values in brackets correspond to the target values; the mean and RSD values were calculated on six different measurements
Table 2 Validation of the repeatability and intermediate precision study

\begin{tabular}{llll}
\hline & QCL & QCM & QCH \\
\hline $\mathrm{CV}_{\mathrm{r}}(\%)^{\mathrm{a}}$ & 0.7 & 1.0 & 1.4 \\
$\mathrm{CV}_{\mathrm{i}}(\%)^{\mathrm{a}}$ & 3.9 & 3.9 & 3.9 \\
\hline
\end{tabular}

$C V_{i}$ coefficient of variation of intermediate precision, $C V_{r}$ coefficient of variation of repeatability, $Q C H$ high quality control, $Q C L$ low quality control, $Q C M$ medium quality control

a The mean and $\mathrm{CV}$ values were calculated on six different measurements

QCH, respectively). Precision contains three components according to the ICH guidelines: repeatability, intermediate precision, and reproducibility (not studied for this latter). Repeatability and intermediate precision are reported in Table 2. Repeatability, expressed as RSD, or coefficient of variation of repeatability $\left(\mathrm{CV}_{\mathrm{r}}\right)$, consisted of the analysis of each QC six times according to the same analytical procedure with the same equipment in the same laboratory. Calibration curves were generated by non-linear Michaelis-Menten-like regression and were validated by quality controls. Intermediate precision evaluates the reliability of the method in an environment other than that used during development of the method. Determination, expressed as RSD or coefficient of variation of intermediate precision $\left(\mathrm{CV}_{\mathrm{i}}\right)$, consisted of the analysis of each QC six times under the same analytical conditions but on multiple days, by different analysts and using different equipment, except the HPTLC workstation. For the forced degradation study, melphalan concentrations were also measured via HPTLC $\mathrm{CAMAG}^{\circledR}$, which is a relevant separating method according to the most recent guidelines for practical stability studies of anti-cancer drugs [15].

\subsection{Physico-Chemical Investigations}

We investigated all admixtures for particulate matter: color change, clarity, and $\mathrm{pH}$ values, which were measured with a digital $\mathrm{pH}$ meter.

Stability was defined as the presence of at least $90 \%$ of melphalan concentration according to reported recommendations [16]. Each sample was analyzed in triplicate. A fivelevel calibration range was set and validated by three levels of QC to conduct the sample analysis of melphalan solutions.

\section{Results}

\subsection{Organoleptic Characteristics}

All the admixtures stored at RT and prepared at $0.5,2$, and $4 \mathrm{mg} / \mathrm{ml}$ remained clear for $24 \mathrm{~h}$. When stored at $5{ }^{\circ} \mathrm{C}$, the 

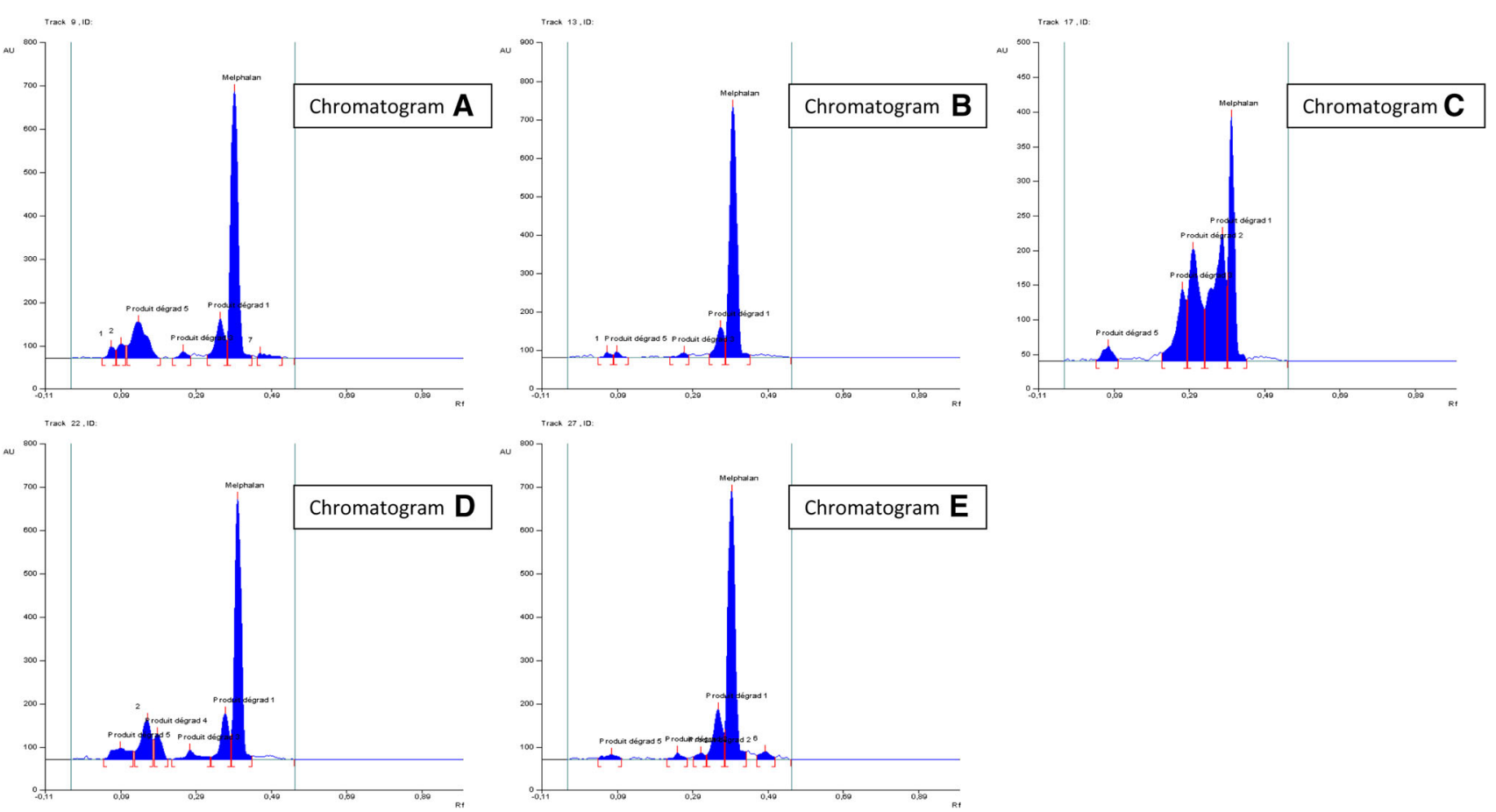

Fig. 2 Chromatograms of $2 \mathrm{mg} / \mathrm{ml}$ melphalan solution submitted to various stress testing of forced degradation study

Table 3 Concentration evolution of melphalan at $4{ }^{\circ} \mathrm{C}$

\begin{tabular}{|c|c|c|c|c|c|c|c|}
\hline & \multicolumn{7}{|l|}{ Hours } \\
\hline & HO & H1 & $\mathrm{H} 2$ & $\mathrm{H} 4$ & H6 & H12 & $\mathrm{H} 24$ \\
\hline \multicolumn{8}{|l|}{0.5} \\
\hline Mean & 0.485 & 0.362 & 0.373 & 0.390 & 0.380 & 0.355 & 0.351 \\
\hline $\begin{array}{l}\text { SD } \\
\Delta(\% \mathrm{Ho})\end{array}$ & $1.41 \times 10^{-3}$ & $\begin{array}{l}4.24 \times 10^{-3} \\
25.3\end{array}$ & $\begin{array}{l}16.97 \times 10^{-3} \\
23.1\end{array}$ & $\begin{array}{l}12.73 \times 10^{-3} \\
19.6\end{array}$ & $\begin{array}{l}15.56 \times 10^{-3} \\
21.6\end{array}$ & $\begin{array}{l}4.95 \times 10^{-3} \\
26.8\end{array}$ & $\begin{array}{l}7.78 \times 10^{-3} \\
27.2\end{array}$ \\
\hline \multicolumn{8}{|l|}{2} \\
\hline Mean & 2.063 & 2.002 & 2.055 & 1.985 & 1.960 & 1.900 & 1.930 \\
\hline $\begin{array}{l}\mathrm{SD} \\
\Delta(\% \mathrm{Ho})\end{array}$ & $4.04 \times 10^{-2}$ & $\begin{array}{l}7.64 \times 10^{-3} \\
3.0\end{array}$ & $\begin{array}{l}6.24 \times 10^{-2} \\
0.4\end{array}$ & $\begin{array}{l}5.07 \times 10^{-2} \\
3.7\end{array}$ & $\begin{array}{l}2.78 \times 10^{-2} \\
5.0\end{array}$ & $\begin{array}{l}5.50 \times 10^{-2} \\
7.9\end{array}$ & $\begin{array}{l}8.66 \times 10^{-3} \\
6.4\end{array}$ \\
\hline \multicolumn{8}{|l|}{4} \\
\hline Mean & 4.230 & 4.053 & 4.167 & 4.120 & 4.160 & 4.100 & 3.917 \\
\hline $\begin{array}{l}\mathrm{SD} \\
\Delta(\% \mathrm{Ho})\end{array}$ & $1.73 \times 10^{-2}$ & $\begin{array}{l}4.93 \times 10^{-2} \\
4.2\end{array}$ & $\begin{array}{l}5.13 \times 10^{-2} \\
1.5\end{array}$ & $\begin{array}{l}1.70 \times 10^{-1} \\
2.6\end{array}$ & $\begin{array}{l}1.17 \times 10^{-1} \\
1.7\end{array}$ & $\begin{array}{l}1.70 \times 10^{-1} \\
3.1\end{array}$ & $\begin{array}{l}1.20 \times 10^{-1} \\
7.4\end{array}$ \\
\hline
\end{tabular}

$S D$ standard deviation

admixtures remained clear at 0.5 and $2 \mathrm{mg} / \mathrm{ml}$ for $24 \mathrm{~h}$. For those prepared at $4 \mathrm{mg} / \mathrm{ml}$, the solution was turbid and colored from $\mathrm{H} 4$.

\subsection{Forced Degradation Study}

Figure 2 shows the results of the forced degradation study for melphalan solutions at $2 \mathrm{mg} / \mathrm{ml}$ in various stressed conditions and after $6 \mathrm{~h}$ of exposition according to the ICH
[14]. Chromatogram A shows the result of a solution of melphalan diluted in $0.9 \%$ sodium chloride solution. Chromatogram B shows the result of a solution of melphalan diluted in $0.1 \mathrm{M} \mathrm{HCl}$. Chromatogram $\mathrm{C}$ shows the result of a solution of melphalan diluted in $0.1 \mathrm{M} \mathrm{NaOH}$. Chromatogram D shows the results of a solution of melphalan diluted in $\mathrm{H}_{2} \mathrm{O}_{2} 10 \%$. Curve $\mathrm{E}$ shows the results of a solution of melphalan diluted in $0.1 \mathrm{M} \mathrm{HCl}$ with zinc powder. The mean of the concentration variation values for 


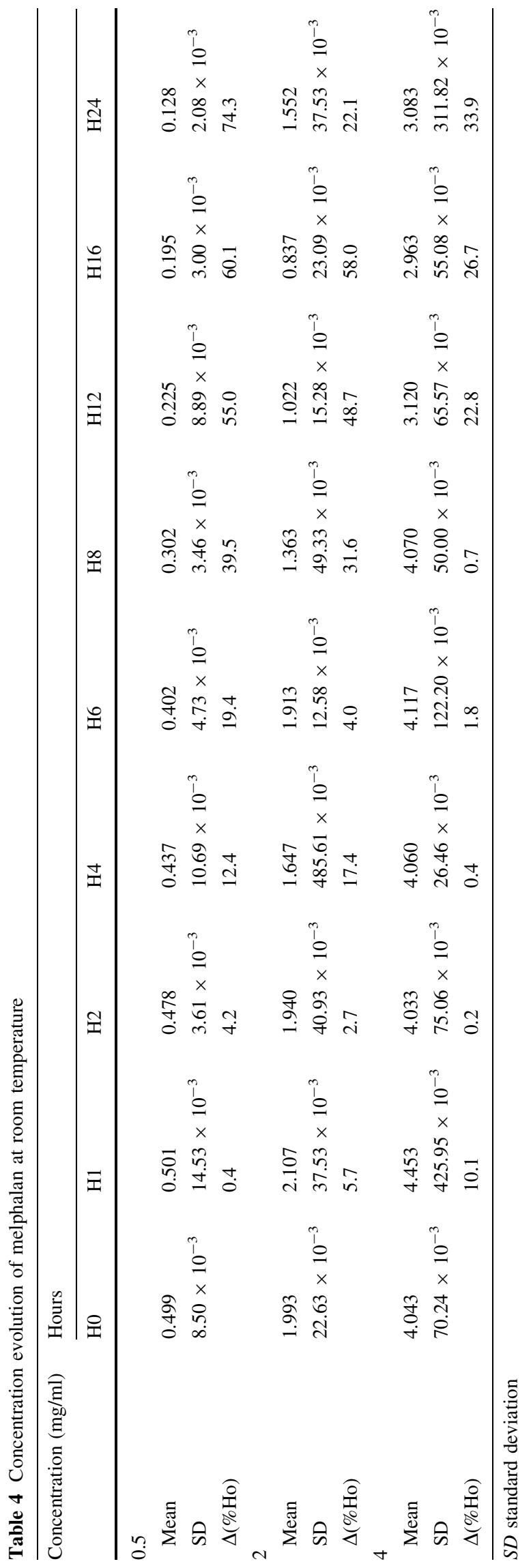

the melphalan solutions after $6 \mathrm{~h}$ of exposure were calculated on six different measurements. The loss of melphalan was calculated at $22.5 \%$ for melphalan diluted in $0.9 \%$ sodium chloride solution, $13.6 \%$ for melphalan diluted in $0.1 \mathrm{M} \mathrm{HCl}, 70.0 \%$ for melphalan diluted in $0.1 \mathrm{M} \mathrm{NaOH}$, $39.1 \%$ for melphalan diluted in $\mathrm{H}_{2} \mathrm{O}_{2} 10 \%$, and $18.4 \%$ for melphalan diluted in $0.1 \mathrm{M} \mathrm{HCl}$ with zinc powder. Evolution of melphalan content in different stress testing conditions shows that melphalan is greatly decreased in alkaline and oxidative conditions, while it remains more stable in acidic conditions. Exposure to strong reductive conditions also shows a decrease of melphalan concentration. On the chromatograms, five peaks of degradation products appears with retention factors (Rf) lower than the Rf obtained for the peak of melphalan. Therefore, the chromatographic method is able to separate its main degradation products and is based on loss of parent compound. No attempt was made to resolve the degradation products completely.

\subsection{Melphalan Concentration Evolution Study}

Table 3 shows that the solutions of melphalan at $0.5 \mathrm{mg} /$ $\mathrm{ml}$ stored at $5{ }^{\circ} \mathrm{C}$ presented the largest changes as compared with $\mathrm{H} 0$. After only $2 \mathrm{~h}$, the calculated change was $23.1 \%$, while at 2 and $4 \mathrm{mg} / \mathrm{ml}$ the variation was limited, with respective degradation percentages calculated at 0.4 and $1.5 \%$. This decrease in melphalan concentrations was also observed at RT as shown in Table 4. When stored at RT, melphalan concentrations decreased between 8 and $12 \mathrm{~h}$ at $4 \mathrm{mg} / \mathrm{ml}(0.7 \%$ of melphalan degraded at $8 \mathrm{~h}$ vs. $22.8 \%$ at $12 \mathrm{~h}$ ). For the solutions stored at RT and prepared at 0.5 and $2 \mathrm{mg} / \mathrm{ml}$, melphalan concentration decreased more rapidly. After $2 \mathrm{~h}$, the respective degradations percentages were 4.2 and $2.7 \%$, and after $4 \mathrm{~h}$ they were 12.4 and $17.4 \%$. Admixtures of melphalan at $4 \mathrm{mg} /$ $\mathrm{ml}$ were more stable than 0.5 and $2 \mathrm{mg} / \mathrm{ml}$ solutions. The different concentrations seemed to have an effect on melphalan stability, as more concentrated solutions (above $2 \mathrm{mg} / \mathrm{ml}$ ) were found to be more stable than diluted solutions $(0.5 \mathrm{mg} / \mathrm{ml})$. Bosanquet [17] explained that this difference is probably due to the faster decrease in $\mathrm{pH}$ due to ion chloride liberation concomitantly to the degradation of melphalan. This phenomenon was found both at low temperatures and at RT. However, concentrations of melphalan decreased more rapidly at RT than at low temperature. For the solutions prepared at 2 and $4 \mathrm{mg} / \mathrm{ml}$ and stored at $4{ }^{\circ} \mathrm{C}$, physical stability was demonstrated for $24 \mathrm{~h}$ (respective degradations of 6.5 and $7.4 \%$ ), while admixtures of melphalan at $0.5 \mathrm{mg} / \mathrm{ml}$ were not stable. At room temperature, stability did not exceed $8 \mathrm{~h}$ for concentrated solutions $(4 \mathrm{mg} / \mathrm{ml})$, and was shorter for diluted solutions. 
Table 5 Summarized results of melphalan stabilities at the two studied storage conditions at 0.5 , 2, and $4 \mathrm{mg} / \mathrm{ml}$

\begin{tabular}{|c|c|c|c|c|}
\hline \multirow[t]{2}{*}{ Concentration $(\mathrm{mg} / \mathrm{ml})$} & \multicolumn{2}{|l|}{ Temperature: $5{ }^{\circ} \mathrm{C}$} & \multicolumn{2}{|l|}{ Temperature: $25^{\circ} \mathrm{C}$} \\
\hline & Organoleptic characteristics & Stability (h) & Organoleptic characteristics & Stability (h) \\
\hline 0.5 & No precipitation & $<1$ & No precipitation & 2 \\
\hline 2 & No precipitation & 24 & No precipitation & 2 \\
\hline 4 & Precipitation & 24 & No precipitation & 8 \\
\hline
\end{tabular}

\section{Discussion}

Solutions of melphalan diluted in PVC bags show limited stability. According to the manufacturer, their stability does not exceed $90 \mathrm{~min}$. The stability of melphalan seems to be longer when infusion bags are stored at refrigerated temperatures than at RTs [9, 10]. Beitz et al. [7] showed that a very diluted concentration $(0.06 \mathrm{mg} / \mathrm{ml})$ of melphalan was stable for $24 \mathrm{~h}$ at $4{ }^{\circ} \mathrm{C}$; however, this low concentration is not usable in practice. Our work was conducted in order to investigate the stability of melphalan at concentrations currently used in hospital practice; the results are summarized in Table 5. The evolution of melphalan concentrations was studied at two temperatures (i.e., $5{ }^{\circ} \mathrm{C}$ and RT). The results of this study generally confirm the data available in the scientific literature. Indeed, the most diluted concentration seemed to show very poor stability. Immediate degradation was observed for the admixture prepared at $0.5 \mathrm{mg} / \mathrm{ml}$ and stored at $4{ }^{\circ} \mathrm{C}$, and stability of $2 \mathrm{~h}$ was found when stored at RT. At $5{ }^{\circ} \mathrm{C}$ as well as at RT, admixtures of melphalan were more stable at high concentrations such as 2 and $4 \mathrm{mg} / \mathrm{ml}$ than at $0.5 \mathrm{mg} /$ $\mathrm{ml}$. Instead, for solutions prepared at $4 \mathrm{mg} / \mathrm{ml}$ and stored at $5{ }^{\circ} \mathrm{C}$, we observed a precipitation phenomenon, which probably comes from the excipients. At RT, no precipitation was observed at any studied concentrations.

Temperature has a counter-intuitive effect on melphalan stability as solutions were more stable when stored at $5{ }^{\circ} \mathrm{C}$ than at RT after preparation. However, concentration levels were also important for the stability of these solutions, as diluted solutions showed higher instability. We conclude that melphalan in $0.9 \%$ sodium chloride at $0.5 \mathrm{mg} / \mathrm{ml}$ is not stable at both temperatures.

\section{Conclusion}

It is a very important challenge for pharmacists working in centralized units to prepare melphalan admixtures at the right time due to its very poor stability. This study shows that, at RT $\left(25 \pm 2{ }^{\circ} \mathrm{C}\right)$, admixtures prepared at $4 \mathrm{mg} / \mathrm{ml}$ can be stored for $8 \mathrm{~h}$ without protection from light. For lower concentrations such as 0.5 and $2 \mathrm{mg} / \mathrm{ml}$, no more than $2 \mathrm{~h}$ of stability can be expected in the same conditions. This work also reports that admixtures prepared at $2 \mathrm{mg} / \mathrm{ml}$ can be stored for $24 \mathrm{~h}$ at refrigerated temperatures $\left(5 \pm 3{ }^{\circ} \mathrm{C}\right)$. Admixtures prepared at 0.5 and $4 \mathrm{mg} /$ $\mathrm{ml}$ are not stable in these conditions, and the advance preparation of melphalan solutions at these concentrations for delayed administration is not recommended.

Acknowledgments This study did not receive any external funding and the authors report no relevant financial conflicts of interest.

Open Access This article is distributed under the terms of the Creative Commons Attribution-NonCommercial 4.0 International License (http://creativecommons.org/licenses/by-nc/4.0/), which permits any noncommercial use, distribution, and reproduction in any medium, provided you give appropriate credit to the original author(s) and the source, provide a link to the Creative Commons license, and indicate if changes were made.

\section{References}

1. Melphalan, Summary of Product Characteristics, Glaxosmithkline, Marly-Le-Roi, France; 2010.

2. Diaz MA, Vicent MG, Madero L. High dose busulfan/melphalan as conditioning for autologous PBPC transplantation in pediatric patients with solid tumors. Bone Marrow Transplant. 1999; 24(11):1157-9.

3. Diaz MA, Lassaletta A, Perez A, Sevilla J, Madero L, GonzalezVicent M. High-dose busulfan and melphalan as conditioning regimen for autologous peripheral blood progenitor cell transplantation in high-risk ewing sarcoma patients: a long-term follow-up single-center study. Pediatr Hematol Oncol. 2010;27(4): 272-82.

4. Pérez-Martínez A, Lassaletta A, González-Vicent M, Sevilla J, Díaz MA, Madero L. High-dose chemotherapy with autologous stem cell rescue for children with high risk and recurrent medulloblastoma and supratentorial primitive neuroectodermal tumors. J Neurooncol. 2005;71(1):33-8.

5. Eggermont AM, Koops HS, Klausner JM, Kroon BB, Schlag PM, Liénard $\mathrm{D}$, et al. Isolated limb perfusion with tumor necrosis factor and melphalan for limb salvage in 186 patients with locally advanced soft tissue extremity sarcomas. The cumulative multicenter European experience. Ann Surg. 1996;224(6):756-64.

6. Beitz C, Einberger C, Wehling M. Stabilität und kompatibilität von zytostatika-zubereitungen mit infusionlösungsbehältern aus polyethylen. Krankenhauspharmazie. 1999;20:121-5.

7. Beitz C, Bertsch T, Hannak D, Schrammel W, Einberger C, Wehling M. Compatibility of plastics with cytotoxic drug solutions - comparison of polyethylene with other container materials. Int J Pharm. 1999;185(1):113-21.

8. Pinguet F, Martel P, Rouanet P, Fabbro M, Astre C. Effect of sodium chloride concentration and temperature on melphalan 
stability during storage and use. Am J Hosp Pharm. 1994;51(21):2701-4

9. Chang SY, Evans TL, Alberts DS. The stability of melphalan in the presence of chloride ion. J Pharm Pharmacol. 1979;31(12): 853-4.

10. Braun B. Stability study of drugs diluted in Ecoflac ${ }^{\circledR}$ bags. B BRAUN AG: Melsungen, Germany; 2001.

11. Paci A, Mercier L, Bourget P. Identification and quantification of antineoplastic compounds in chemotherapeutic infusion bags by use of HPTLC: application to the vinca-alkaloids. J Pharm Biomed Anal. 2003;30:1603-10.

12. Bourget P, Paci A, Rey JB, Mercier L, Demirdjian S. Contribution of high-performance thin-layer chromatography to a pharmaceutical quality assurance programme in a hospital chemotherapy manufacturing unit. Eur J Pharm Biopharm. 2003;56(3):445-51.
13. Borget I, Laville I, Paci A, et al. Application of an acceptance sampling plan for post-production quality control of chemotherapeutic batches in an hospital pharmacy. Eur J Pharm Biopharm. 2006;64(1):92-8.

14. US Food and Drug Administration. Validation of analytical procedures: methodology ICH (Q2B). 1996. http://www.fda.gov/ downloads/drugs/guidancecomplianceregulatoryinformation/ guidances/ucm073384.pdf. Accessed 4 Jul 2015.

15. Bardin C, Astier A, Vulto A, et al. Guidelines for the practical stability studies of anticancer drugs: a European consensus conference. Ann Pharm Fr. 2011;69(4):221-31.

16. Trissel LA, Flora KP. Stability studies: five years later. Am J Hosp Pharm. 1988;45(7):1569-71.

17. Bosanquet AG. Stability of melphalan solutions during preparation and storage. J Pharm Sci. 1985;74(3):348-51. 